SŁAWOMIR DoROCKI

Uniwersytet Pedagogiczny w Krakowie, Polska - Pedagogical University of Cracow, Poland

RaFAL KROCZAK

Uniwersytet Pedagogiczny w Krakowie, Polska - Pedagogical University of Cracow, Poland

TOMASZ BRYNDAL

Uniwersytet Pedagogiczny w Krakowie, Polska - Pedagogical University of Cracow, Poland

\title{
Zmiany pokrycia terenu w polskich Karpatach na przełomie XX i XXI w. a poziom rozwoju lokalnego
}

\author{
Changes in the Land Cover in the Polish Carpathians \\ at the Turn of the 20th and 21st Century in Relation to Local Development Level
}

Streszczenie: W niniejszym artykule ukazano zależności pomiędzy zmianami pokrycia terenu a poziomem rozwoju lokalnego w polskich Karpatach. Badania prowadzono w jednostkach administracyjnych (miasta i wsie). Zmiany w pokryciu terenu analizowano na podstawie danych $\mathrm{z}$ bazy Corine Land Cover z lat 1990-2012, korzystając z autorskiego wskaźnika: zmian struktury pokrycia terenu (LC). Poziomu rozwoju lokalnego określono na podstawie danych statystycznych pochodzących z bazy danych lokalnych GUS (gęstość zaludnienia, wielkość budownictwa mieszkaniowego oraz liczba podmiotów gospodarczych). Na ich podstawie obliczono syntetyczny wskaźnik rozwoju społeczno-gospodarczego (LD). W celu określenia zależności pomiędzy zmianami pokrycia terenu a poziomem rozwoju lokalnego wykorzystano modele mieszane (mixed model). W pierwszym modelu za wartość $y(L D)$ przyjęto obliczony indeks lokalnego rozwoju. W drugim modelu za wartość $y(L C)$ przyjęto zmiany struktury pokrycia terenu. W pierwszym modelu jako zmienne wykorzystano wskaźniki obrazujące rozwój lokalny w $2011 \mathrm{r}$. W drugim modelu zmiennymi były wielkości zmiany udziału pokrycia terenu w latach 1990-2012 w poszczególnych klasach. Uzyskane wyniki wykazały wzrost udziału obszarów o luźnej zabudowie, co świadczy o procesach suburbanizacji oraz naporze inwestycyjnym - głównie na obszarach podmiejskich i atrakcyjnych turystycznie. Znaczące zmiany pokrycia terenu zidentyfikowane w obszarach atrakcyjnych turystycznie były związane z rozwojem infrastruktury turystycznej oraz zanikiem funkcji rolniczych tych miejscowości.

Abstract: In the paper the relations between land cover changes and the level of local development in the
Polish Carpathians were analysed. The analyses were carried out based on administrative units (towns
and villages) and data of land cover from 1990-2012 were used. In order to detect the dominant land
cover changes in the period analysed, the land cover change indicator (LC) was developed. In order to
rate the level of local development, local statistical data, collected by the Central Statistical Office in
Poland database were used. On the basis of the data, a synthetic indicator of socio-economic develop-
ment (LD) was calculated. To calculate the indicator, the following were used: population density, the
number of newly built flats/houses, and the number of business companies. In order to build a model
that would show the relations between the local development and changes in land cover, a mixed mod-
el was constructed. Two options were checked in the analysis. In the first model, the value of $y(L D)$ 
was assumed by the calculated indicator of local development. In the second model, $y(L C)$ value was described by calculating the land cover changes indicator. In the first case, indicators showing local development in 2011 were used as variables. In the second case, the variables were the changes of the land cover (1990-2012) in each of the classes. The analyses carried out show an increase in the share of discontinuous urban areas, which indicates suburbanisation processes and local developers (investment) pressure - mainly in suburban and areas attractive for tourist. Significant changes in land cover, identified in the areas attractive for tourists, were related to the development of tourist infrastructure and the disappearance of agricultural functions.

Słowa kluczowe: Karpaty; pokrycie terenu; Polska; rozwój lokalny

Key words: Carpathian Mountains; land cover; local development; Poland

Otrzymano: 2 stycznia 2018

Received: 2 January 2018

Zaakceptowano: 20 lutego 2019

Accepted: 20 February 2019

\section{Sugerowana cytacja/Suggested citation:}

Dorocki, S., Kroczak, R., Bryndal, T. (2019). Zmiany pokrycia terenu w polskich Karpatach na przełomie XX i XXI w. a poziom rozwoju lokalnego. Przedsiębiorczość - Edukacja [Entrepreneurship Education], 15(1), 214-229. doi: 10.24917/20833296.151.16

\section{Wstęp}

Ostatnie stulecie było okresem niezwykle dynamicznego postępu cywilizacyjnego i technicznego na świecie i zarazem okresem istotnych zmian społeczno-politycznych i gospodarczych w Polsce. W XX w. w naszym kraju wyróżniono trzy „klasyczne” okresy w rozwoju społeczno-gospodarczego kraju: lata międzywojenne 1918-1939, epokę gospodarki planowej 1945-1989 oraz okres po 1989 roku, kiedy to nastąpiły ważne zmiany polityczne i gospodarcze (Kukliński, 2007). Uważa się (Harańczyk, 2015), że nowe warunki gospodarowania oraz nasilający się proces globalizacji, mające miejsce pod koniec XX w., doprowadziły do przemian w strukturze użytkowania i sposobie zagospodarowania na obszarze Polski.

Zachodzące współcześnie zmiany w pokryciu terenu wynikają głównie z: rozwoju gospodarczego, inwestycji, polityki rolnej oraz prawnie uwarunkowanych działań na rzecz ochrony krajobrazu. Istotnym czynnikiem wpływającym również na zmiany w użytkowaniu terenu jest ewolucja potrzeb i stylu konsumpcji, wynikająca ze wzrostu zamożności społeczeństwa oraz jego postaw przedsiębiorczych (Matyka, 2012).

Istotne zmiany w użytkowaniu terenu w Polsce obserwujemy nie tylko na obszarach aktywnych gospodarczo, ale również na mniej rozwiniętych, lecz atrakcyjnych turystycznie obszarach górskich. To właśnie w Karpatach w ostatnich dziesięcioleciach miały miejsce znaczące przekształcenia użytkowania ziemi wymuszone zmianami społeczno-gospodarczymi: m.in. spadkiem opłacalności uprawy, emigracją - depopulacją, rozwojem usług turystycznych itp. (np. Bucała, Starkel, 2012). Zmiany w użytkowaniu ziemi, a w konsekwencji - w pokryciu terenu - nasiliły się szczególnie w okresie transformacji gospodarczej, tj. po 1989 r. (Górz, 2003). Z jednej strony cechowały się one istotnym zmniejszaniem udziału gruntów ornych (Bański, 2003; Kozak 2005; Zabierowski, 1995) - jak wskazuje Sikora (2012), w XXI w. województwa małopolskie i podkarpackie charakteryzowały 
się największym spadkiem udziału terenów rolniczych w Polsce, wynoszącym ok. 35\%. Z drugiej strony, wzrost zamożności społeczeństwa obserwowany w ostatnich latach i związany z tym wzrost popytu na usługi czasu wolnego, w tym usługi spa \& welles, turystykę eventową i usługi ściśle związane z terenami górskimi usługi świadczone przez ośrodki narciarskie (Dorocki 2016; Dorocki, Brzegowy, 2014; Dorocki i in. 2014), przyczyniły się do intensyfikacji inwestycji i aktywności gospodarczej, głównie na obszarach atrakcyjnych turystycznie. Obszary takie są od lat pod naporem inwestycji developerów, co ma związek z procesami suburbanizacji oraz problemem „drugich domów” (Mika, 2012; Mika, Faracik, 2008).

Jak zatem wskazuje literatura przedmiotu, zmiany pokrycia terenu są silnie powiązane z przemianami społeczno-gospodarczymi zachodzącymi na różnych poziomach organizacji oraz w różnych układach przestrzennych, a kierunek i tempo tych zmian są w znacznej mierze uwarunkowane zarówno czynnikami przyrodniczymi, jak i społeczno-ekonomicznymi, które występują na danym obszarze. Wydaje się, że na poziomie lokalnym spośród czynników społeczno-ekonomicznych szczególny wpływ na kierunek oraz tempo zmian pokrycia terenu mają: aktywność społeczna, wyrażona w postawach przedsiębiorczych, oraz prawne i kulturowe uwarunkowania, które tę aktywność warunkują (Dorocki 2008). Mając na uwadze powyższe prawidłowości, można się spodziewać, że najsilniejsze zmiany w pokryciu terenu będą miały miejsce w regionach o największej aktywności gospodarczej (np. nowe inwestycje w infrastrukturę) oraz w regionach, gdzie miały miejsce zmiany dotychczasowych funkcji gospodarczych. Zatem celem pracy jest próba odpowiedzi na pytania: czy i na ile zmiany pokrycia terenu obserwowane w Karpatach polskich są związane z poziomem rozwoju lokalnego?

\section{Teren badań}

W obrębie Karpat polskich (Solon i in., 2018) wydzielono trzy główne jednostki fizycznogeograficzne (Pogórza, Beskidy i Tatry), które dzielą się na mniejsze jednostki - makroregiony (rycina 1). Przestrzenne rozmieszczenie jednostek fizycznogeograficznych w znacznej mierze warunkuje budowa geologiczna oraz zależna od niej rzeźba terenu. Elementy te wpływają na zróżnicowanie pozostałych komponentów środowiska geograficznego oraz warunkują sposoby gospodarowania w przestrzeni geograficznej (por. Warszyńska, 1996). Pogórza (rycina 1- 6) i (11)) budują formy terenu o szerokich wierzchowinach i łagodnych stokach $\left(10-20^{\circ}\right)$.

Rzeźba terenu, pokrywa glebowa oraz warunki klimatyczne powodują, że Pogórza Karpackie są obszarem, gdzie dominują użytki rolne. Beskidy (rycina 1 - (7) (8) (12) i (13) to obszary o wyższych wysokościach tak względnych, jak i bezwzględnych (przekraczających w najwyższych partiach 1000 m n.p.m.) oraz większych nachyleniach stoków $\left(20-50^{\circ}\right)$. Górne części stoków są przeważnie zalesione. Środkowe i dolne części stoków (o mniejszym nachyleniu) oraz dna dolin i kotlin śródgórskich zajmują użytki rolne. Tam też koncentruje się osadnictwo (Warszyńska, 1996). Na południu, przy granicy ze Słowacją, zlokalizowany jest obszar wysokogórski; niezamieszkały, o charakterze turystycznym i w większości chroniony w ramach parku narodowego (rycina 1 - (9)). Badaniami objęto obszar wysunięty dalej na północ aniżeli granica fizycznogeograficzna Karpat, tworząc kilkunastokilometrowy bufor obejmujący przedgórze Karpat wraz z najważniejszymi miastami tego pasa (Kraków, Tarnów, Dębica, Rzeszów, Przemyśl itp.). 
Rycina 1. Położenie obszaru badań na tle nachyleń terenu w Karpatach

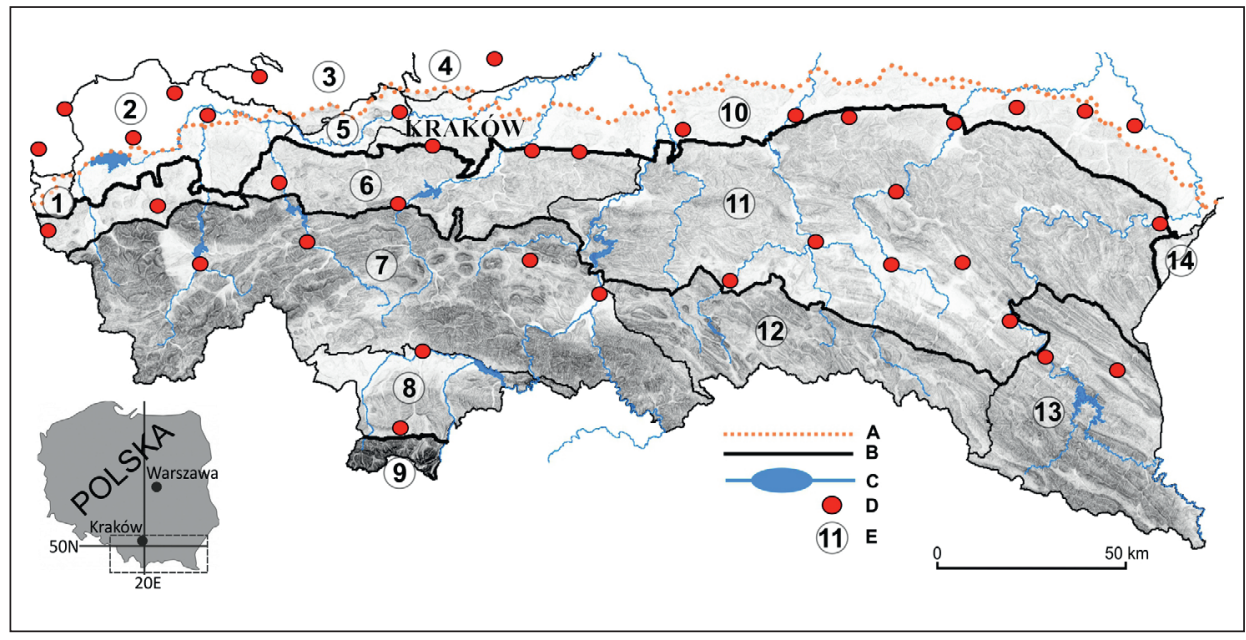

A - granica opracowania; B - granice jednostek fizycznogeograficznych - makroregiony; C - główne rzeki i zbiorniki zaporowe; D - siedziby powiatów; E - nazwy makroregionów (1. Kotlina Orawska, 2. Kotlina Oświęcimska, 3. Wyżyna Krakowsko-Częstochowska, 4. Niecka Nidziańska, 5. Brama Krakowska, 6. Pogórze Zachodniobeskidzkie, 7. Beskidy Zachodnie, 8. Obniżenie Orawsko-Podhalańskie, 9. Łańcuch Tatrzański, 10. Kotlina Sandomierska, 11. Pogórze Środkowobeskidzkie, 12. Beskidy Środkowe, 13. Beskidy Lesiste, 14. Płaskowyż Sańsko-Dniestrzański)

\section{Materiały i metody}

Aby zrealizować postawiony cel badań, wykonano analizy danych statystycznych i przestrzennych dla okresu 1990-2012. Ramy czasowe analizy obejmują okres najsilniejszych przemian społeczno-gospodarczych mających miejsce w Polsce w okresie transformacji systemowej (Rachwał, 2010). Dane o pokryciu terenu pobrano z bazy Corine Land Cover (CLC). Program CLC jest realizowany przez European Environment Agency (http:// www.eea.europa.eu/). Jego podstawowym celem jest dokumentowanie zmian w pokryciu terenu w krajach europejskich (Bossard i in., 2000; Corine i in., 1994). Program zbiera dane o pokryciu terenu na trzech poziomach szczegółowości. Na poziomie trzecim wyróżniono 44 klasy i ten poziom szczegółowości wykorzystano w niniejszych badaniach. Przyjęte klasy wydzielane są w całej Unii Europejskiej (i krajach partnerskich, np. Turcji) na podstawie tych samych kryteriów, a minimalna powierzchnia jednolitego poligonu wynosi 25 ha. W przypadku dużej mozaiki typów użytkowania terenu poligon przyjmuje wartość dominującego typu.

Dotychczas wykonano cztery edycje map dla lat: 1990, 2000, 2006 i 2012 (rok edycji nie jest równoznaczny z datą danych, na podstawie których wykonano mapy, w Polsce przesunięcia w czasie mogą wynosić ponad jeden rok) (Baranowski, Ciołkosz, 1997, 2004). Na podstawie danych z edycji 1990 i 2012 wykonano bazy struktury pokrycia terenu dla wszystkich jednostek administracyjnych Karpat. W przyjętym do analiz obszarze wyróżniono 28 klas pokrycia terenu w roku 2012 i 27 klas w roku 1990. Pełne polskie nazwy klas pokrycia terenów zdefiniowanych w programie CLC oraz ich skróty użyte w tekście przedstawiono w tabeli 1. 
Tabela 1. Klasy pokrycie trenu wg programu CLC oraz zmiany ich udziału w latach 1990 i 2012 w Karpatach

\begin{tabular}{|c|c|c|c|c|c|}
\hline $\begin{array}{l}\text { Kod } \\
\text { CLC }\end{array}$ & Pełna polska nazwa klasy & $\begin{array}{l}\text { Skrót używany } \\
\text { w tekście } \\
\text { i na rycinach }\end{array}$ & $\begin{array}{l}\text { Udział w pow. } \\
\text { terenu badań } \\
\text { w } 1990 \mathrm{r} . \mathrm{w} \%\end{array}$ & $\begin{array}{r}\mathrm{Zm} \\
\text { udzial } \\
\text { teren }\end{array}$ & 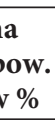 \\
\hline 111 & Zabudowa miejska zwarta & zabudowa zwarta & 0,04 & $-0,01$ & $\downarrow$ \\
\hline 112 & Zabudowa miejska luźna & zabudowa luźna & 3,53 & $+3,24$ & $\uparrow$ \\
\hline 121 & $\begin{array}{l}\text { Tereny przemysłowe lub } \\
\text { handlowe }\end{array}$ & tereny przemysłowe & 0,36 & $+0,08$ & $\uparrow$ \\
\hline 122 & $\begin{array}{l}\text { Tereny komunikacyjne } \\
\text { i związane z komunikacją } \\
\text { drogową i kolejową }\end{array}$ & $\begin{array}{l}\text { tereny } \\
\text { komunikacyjne }\end{array}$ & 0,03 & $+0,07$ & $\uparrow$ \\
\hline 124 & Lotniska & lotniska & 0,01 & $+0,02$ & $\uparrow$ \\
\hline 131 & $\begin{array}{l}\text { Miejsca eksploatacji } \\
\text { odkrywkowej }\end{array}$ & $\begin{array}{l}\text { kopalnie } \\
\text { odkrywkowe }\end{array}$ & 0,04 & $+0,07$ & $\uparrow$ \\
\hline 132 & Zwałowiska i hałdy & hałdy & 0,01 & $+0,00$ & $\uparrow$ \\
\hline 133 & Budowy & budowy & 0,04 & $+0,09$ & $\uparrow$ \\
\hline 141 & Tereny zielone & miejskie t. zielone & 0,07 & $-0,03$ & $\downarrow$ \\
\hline 142 & $\begin{array}{l}\text { Tereny sportowe } \\
\text { i wypoczynkowe }\end{array}$ & tereny rekreacyjne & 0,08 & $+0,05$ & $\uparrow$ \\
\hline 211 & $\begin{array}{l}\text { Grunty orne poza zasięgiem } \\
\text { urządzeń nawadniających }\end{array}$ & grunty orne & 27,78 & $+1,40$ & $\uparrow$ \\
\hline 222 & Sady i plantacje & sady & 0,14 & $+0,09$ & $\uparrow$ \\
\hline 231 & Łąki, pastwiska & użytki trawiaste & 6,36 & $-1,03$ & $\downarrow$ \\
\hline 242 & \begin{tabular}{|l|} 
Złożone systemy upraw \\
i działek
\end{tabular} & $\begin{array}{l}\text { złożone systemy } \\
\text { upraw i działek }\end{array}$ & 12,59 & $-5,38$ & $\downarrow$ \\
\hline 243 & $\begin{array}{l}\text { Tereny zajęte głównie przez } \\
\text { rolnictwo z dużym udziałem } \\
\text { roślinności naturalnej }\end{array}$ & $\begin{array}{l}\text { tereny górskie } \\
\text { o dużym udziale } \\
\text { rolnictwa }\end{array}$ & 9,20 & $-2,08$ & $\downarrow$ \\
\hline 311 & Lasy liściaste & lasy liściaste & 10,02 & $+0,68$ & $\uparrow$ \\
\hline 312 & Lasy iglaste & lasy iglaste & 12,73 & $+0,28$ & $\uparrow$ \\
\hline 313 & Lasy mieszane & lasy mieszane & 14,65 & $+1,52$ & $\uparrow$ \\
\hline 321 & $\begin{array}{l}\text { Murawy i pastwiska } \\
\text { naturalne }\end{array}$ & $\begin{array}{l}\text { murawy i pastwiska } \\
\text { naturalne }\end{array}$ & 0,48 & $-0,14$ & $\downarrow$ \\
\hline 322 & Wrzosowiska i zakrzaczenia & wrzosowiska & 0,13 & $+0,01$ & $\uparrow$ \\
\hline 324 & $\begin{array}{l}\text { Lasy i roślinność krzewiasta } \\
\text { w stanie zmian }\end{array}$ & $\begin{array}{l}\text { zaawansowana } \\
\text { sukcesja natur. }\end{array}$ & 0,53 & $+0,91$ & $\uparrow$ \\
\hline 332 & Odsłonięte skały & skały & 0,12 & $-0,02$ & $\downarrow$ \\
\hline 333 & Roślinność rozproszona & $\begin{array}{l}\text { roślinność } \\
\text { rozproszona }\end{array}$ & 0,00 & $+0,01$ & $\uparrow$ \\
\hline 334 & Pogorzeliska & pogorzeliska & 0,00 & $+0,00$ & $\uparrow$ \\
\hline 411 & Bagna śródlądowe & bagna & 0,05 & $-0,02$ & $\downarrow$ \\
\hline 412 & Torfowiska & torfowiska & 0,07 & $-0,01$ & $\downarrow$ \\
\hline 511 & Cieki & cieki & 0,22 & $+0,03$ & $\uparrow$ \\
\hline 512 & Zbiorniki wodne & zbiorniki wodne & 0,72 & $+0,17$ & $\uparrow$ \\
\hline
\end{tabular}

Źródło: opracowanie własne 
Jako macierz jednostek administracyjnych przyjęto spis miejscowości do celów statystycznych (SIMC) dla roku 2011. Łącznie badaniami objęto 2187 wsi i 79 miast, dowiązując do poligonu każdej z miejscowości atrybuty opisujące strukturę pokrycia terenu i dane statystyczne opisujące poziom rozwoju.

Do oceny poziomu rozwoju lokalnego wykorzystano dane statystyczne zaczerpnięte z bazy danych lokalnych GUS. W związku z brakiem uniwersalnych charakterystyk opisujących poziom rozwoju lokalnego na poziomie miejscowości statystycznych (Sołtys, Dorocki, 2016) wykorzystano zmienne zastępcze (surrogate), z których obliczono syntetyczny wskaźnik rozwoju społeczno-gospodarczego. Były nimi: gęstość zaludnienia, wielkość budownictwa mieszkaniowego oraz liczba podmiotów gospodarczych. Aby osłabić czasowe fluktuacje związane ze zmianą wielkości poszczególnych zmiennych, w analizie wykorzystano wartości średnie dla lat 2009-2012 zamiast pojedynczych danych dla roku 2011. Autorzy w trakcie analiz byli świadomi kryzysu gospodarczego, który miał miejsce w okresie badań, jednakże jego skutki były odczuwalne we wszystkich jednostkach administracyjnych, dlatego pominięto jego znaczenie. Jedynie można uznać, że kryzys mógł uwypuklić istniejące różnice w poziomie rozwoju społeczno-gospodarczego badanego obszaru (Dorocki, 2011; Rachwał, 2011). Aby ułatwić analizę tekstu, sposób obliczenia wskaźnika jest przedstawiony w odpowiedniej części opracowania.

$\mathrm{W}$ analizie wykorzystano metody statystyczne, a wyniki zaprezentowano $\mathrm{w}$ formie kartogramów i wykresów. W celu budowy modelu zmian pokrycia trenu i wielkości poziomu rozwoju gospodarczego wykorzystano model mieszany (mixed model), gdzie do kowariancji struktury zastosowano funkcję wykładniczą. Zastosowana procedura PROC MIXED opiera się na metodzie ograniczonego maksymalnego prawdopodobieństwa (REML), znanej również jako resztkowe maksymalne prawdopodobieństwo. Szczegóły opisano w odpowiedniej części tekstu.

\section{Wyniki badań}

\section{Zmiany pokrycia terenu}

W okresie 1990-2012 nastąpiły zauważalne zmiany w strukturze pokrycia terenu w Karpatach polskich (tabela 1). Najbardziej widoczny jest wzrost udziału luźnej zabudowy, który nastąpił głównie kosztem złożonych systemów upraw i działek (rycina 2), czyli tradycyjnych „ulicówek”, gdzie posesje otaczają przydomowe ogrody i poletka. Zmiana polegała głównie na zagęszczeniu istniejącej zabudowy, co zaowocowało w badanym okresie przejściem z jednej do drugiej klasy pokrycia terenu. Było to związane zarówno z procesem suburbanizacji, jak i naporem inwestycyjnym w obszarach atrakcyjnych turystycznie (Serafin, 2016; Trzepacz, 2011). Nastąpił również wzrost udziału gruntów ornych kosztem użytków trawiastych, co miało związek ze zmianą struktury rolnictwa i m.in. uruchomieniem systemu dopłat po wejściu Polski do UE. W badanym okresie nastąpił także wzrost powierzchni lasów. Wzrostu tego nie można było statystycznie powiązać ze spadkiem udziału konkretnej klasy pokrycia terenu. Na podstawie literatury można jednak domniemywać, że odbył się on głównie kosztem użytków rolniczych w terenach górskich (Bucała, 2014; Kaim, 2009; Kroczak i in., 2018). Zmniejszenie udziału muraw i pastwisk naturalnych spowodowane było z jednej strony spadkiem hodowli (Zarzycki, Korzeniak, 2013) i związanym z tym zanikiem działalności rolniczej w regionach górskich 
Rycina 2. Zmiany pokrycia terenu w polskich Karpatach w latach 1990 i 2012

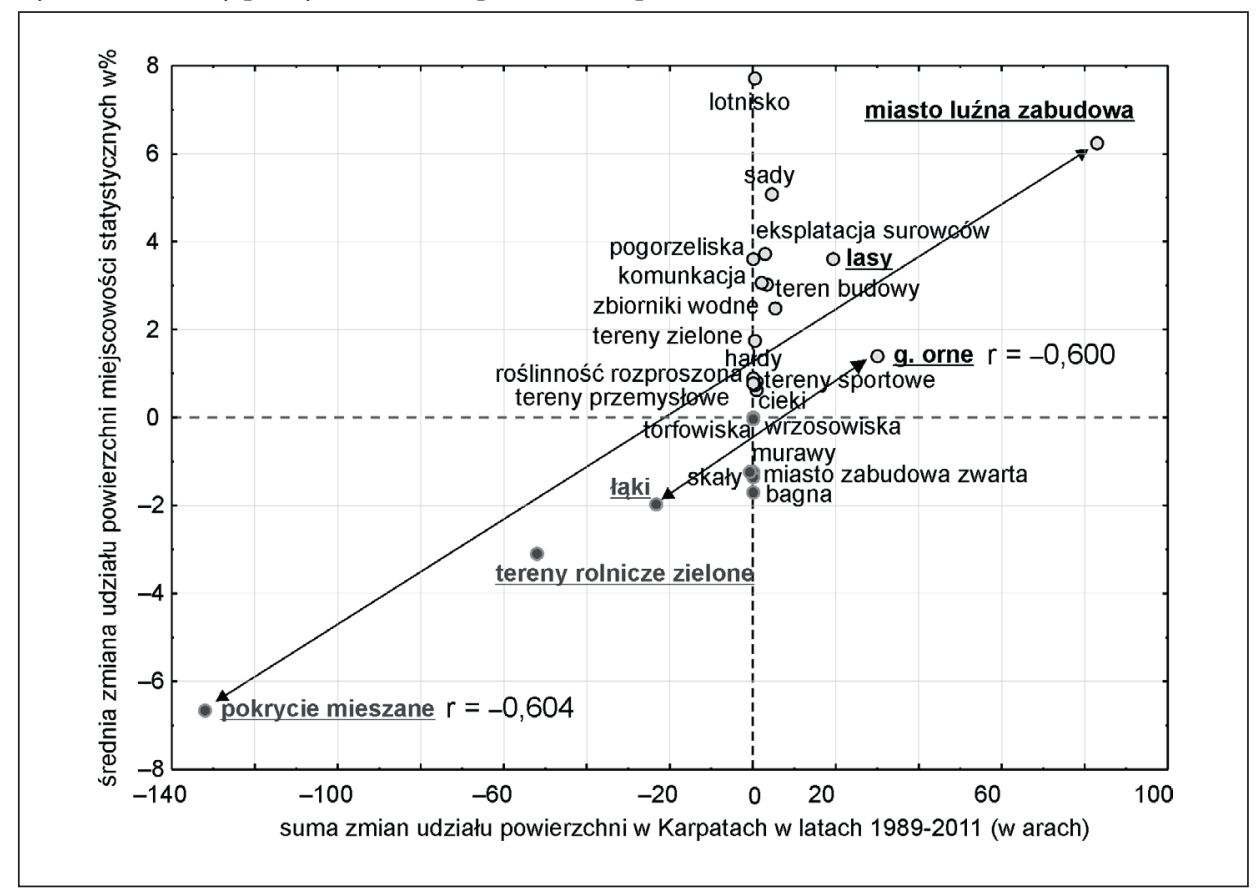

Źródło: opracowanie własne

(w tym upadkiem PGR-ów, np. w Tarnawie Wyżnej, Izbach, Owczarach), a z drugiej strony wynikało z sukcesji naturalnej (Kroczak i in., 2018).

Aby określić największe zmiany pokrycia terenu w polskich Karpatach w nawiązaniu do jednostek administracyjnych (miast i wsi), opracowano wskaźnik zmiany struktury pokrycia terenu (LC). W tym celu na podstawie ilorazu szans oraz funkcji logitowej obliczono zmianę struktury pokrycia terenu Karpat dla lat 1990 i 2012:

gdzie:

$$
L C=\sum_{n=1}^{n=N}\left|\frac{\log \left(\frac{P_{n}(A)}{1-P_{n}(A)}\right)}{\log \left(\frac{P_{n}(B)}{1-P_{n}(A B)}\right)}\right|
$$

$\mathrm{P}(\mathrm{A})$ - udział powierzchni w $1990 \mathrm{r}$.,

$\mathrm{P}(\mathrm{B})$ - udział powierzchni w 2012 r.,

$\mathrm{n}$ - rodzaj pokrycia terenu.

Aby uniknąć dzielenia przez zero w przypadku braku udziału danej cechy, podstawiono minimalną wartość cechy dla badanego obszaru dzieloną dodatkowo przez pół. Z otrzymanych wartości logitudowych obliczono wartość bezwzględną, a następnie dokonano ich sumowania, otrzymując wskaźnik.

Analizując przestrzenny rozkład wartości wskaźnika LC, można zauważyć trzy głównie prawidłowości. Największe zmiany pokrycia terenu nastąpiły wokół dużych miast, co miało związek ze wzrostem udziału zabudowy luźnej kosztem złożonych systemów 
Rycina 3. Wartości wskaźnika zmiany struktury pokrycia terenu w miejscowościach polskich Karpat w latach 1990 i 2012

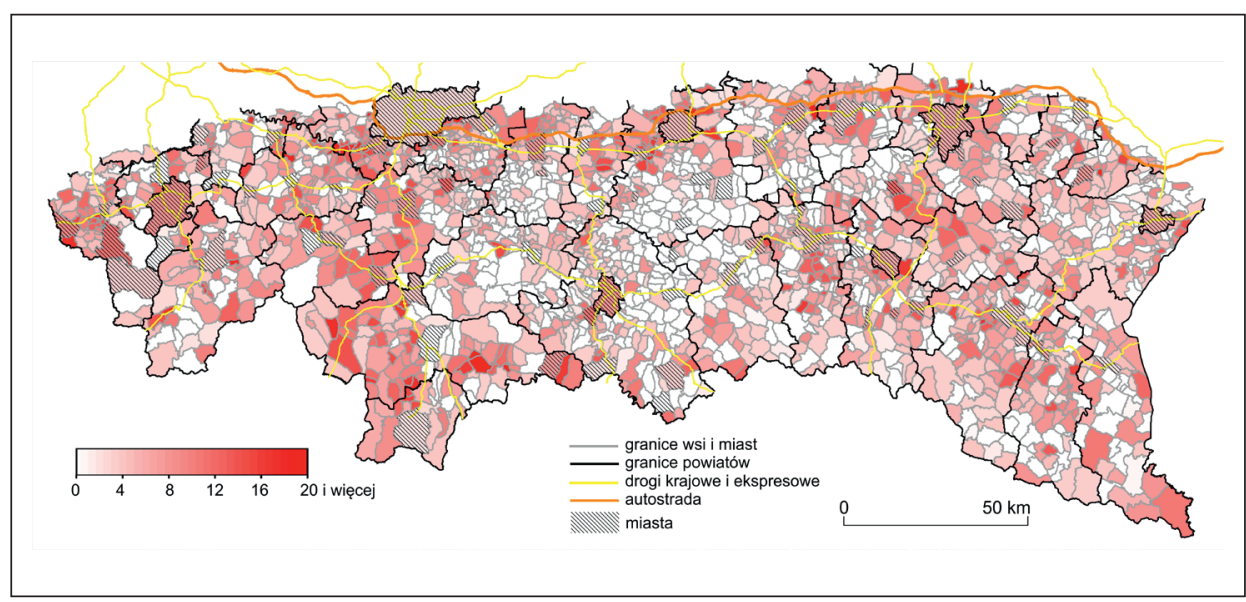

Źródło: opracowanie własne

upraw i działek. Następną prawidłowością jest zmiana struktury pokrycia wzdłuż ciągów komunikacyjnych będących obszarami rozwoju gospodarczego oraz kanałami mobilności mieszkańców miast związanym z efektem spillover (Jensen, 2018). Po trzecie, wysoki wskaźnik LC odnotowały obszary atrakcyjne turystycznie, głównie Podhale i Beskidy. $\mathrm{Na}$ tych górzystych terenach nastąpił wyraźny spadek terenów rolnych, co związane było z nieopłacalnością produkcji oraz rozwojem usług turystycznych.

\section{Zmiana pokrycia terenu a poziom rozwoju lokalnego}

W celu określenia poziomu lokalnego rozwoju społeczno-gospodarczego posłużono się trzema różnymi kryteriami, dla których obliczono wartości średnie dla lat 2009-2012. Jak wspomniano, miało to na celu wyeliminowanie wahań związanych z cyklami koniunktury oraz czynnikami losowymi, które w przypadku analizy na tak szczegółowym poziomie jak miejscowości statystyczne, mogły mieć duże znaczenie. W przeprowadzonej analizie poziomu rozwoju lokalnego posłużono się następującymi danymi: gęstością zaludnienia, wielkością budownictwa mieszkaniowego oraz liczbą podmiotów gospodarczych. Nadmienić należy, że poziom rozwoju społeczno-gospodarczego jest trudny do określenia, a stosowane wskaźniki często poddawane są krytyce ze względu na złożoność problematyki rozwoju społeczno-gospodarczego (Kurek i in., 2016; Sołtys, Dorocki, 2016).

Zakłada się, że gęstość zaludnienia jest silnie skorelowana z poziomem rozwoju społeczno-gospodarczego - zarówno terenów wiejskich, jak i miast (Czyż, 2012; Szymańska i in., 2006). Jednakże samego zróżnicowania gęstości zaludnienia nie można rozważać jako poziomu rozwoju społeczno-gospodarczego terenów wiejskich, a jedynie jako jeden ze wskaźników składowych rozwoju społeczno-ekonomicznego (Bański, 2002). Gęstość zaludnienia jest zatem miernikiem wskazującym pośrednio na stopień zagospodarowania obszaru, charakter i gęstość osadnictwa, zasoby pracy itp. Wzrost gęstości zaludnienia oznacza na ogół rozwój społeczno-gospodarczy obszaru, zaś spadek - niekorzystne procesy ekonomiczne (Bański, Stola, 2002). Niska gęstość zaludnienia może być również 
czynnikiem hamującym rozwój. J.S. Zegar (2012) określa tzw. zaklęty krąg, w którym niska gęstość zaludnienia powoduje brak krytycznej masy dla rozwoju usług publicznych i infrastruktury. Owa niska stopa kreacji biznesu wpływa na ograniczenie miejsc pracy, co w kolei wiąże się z procesem migracji i starzenia się ludności. Wszystkie te procesy wpływają na konsekwentne zmniejszanie się gęstości zaludnienia (Zegar, 2012).

Następnym z przyjętych wskaźników była wielkość budownictwa mieszkalnego. Za przyjęciem takiego wskaźnika rozwoju przemawia fakt, że rynek nieruchomości jest zależny w dużej mierze od poziomu rozwoju gospodarczego (Mach, 2012). Wielkość popytu na mieszkania uwarunkowana jest hierarchizacją potrzeb, gdzie mieszkanie klasyfikowane jest jako potrzeba pierwszego rzędu (Maslow, 1987). Również ważnym aspektem tego dobra jest jego powszechność, która pozwala na przestrzenną analizę natężenia zjawiska. Dodatkowo mieszkanie ma zarówno aspekt finansowy, jak i odnosi się do stanu posiadania materialnego (Foryś, 2011; Grum, Temeljotov-Salaj, 2010) oraz stanowi często formę inwestycji jako sposób alokacji kapitału (Wolski, Załęczna, 2007). W Polsce posiadanie domu lub mieszkania ma również aspekt psychologiczny, wywołuje poczucie bezpieczeństwa oraz utrwala zajmowaną pozycję społeczną (Andrews i in., 2011). Kupno domu lub mieszkania świadczy o awansie społecznym, który często związany jest z lokalnym rozwojem gospodarczym. W przeprowadzonej analizie pominięto czynniki społeczno-demograficzne (Witakowski, 2007) i prawne, które również w znaczący sposób wpływają na rynek nieruchomości.

Ostatnim przyjętym wskaźnikiem rozwoju lokalnego była liczba podmiotów gospodarczych na 100 mieszkańców, gdyż aktywność gospodarcza powiązana jest także z poziomem przedsiębiorczości (Ziemiańczyk, 2010). Rozwój przedsiębiorczości w skali lokalnej i ponadlokalnej oraz jej wpływ na aktywizację gospodarczą przejawiają się przede wszystkim wzrostem liczby podmiotów gospodarczych (głównie małych firm i mikrofirm). Firmy te, zwiększając rynek pracy, powodują wzrost dochodów ludności z pracy i dochodów samorządowych, przyczyniając się tym samym do ograniczenia bezrobocia (Zioło, 2007).

Na podstawie powyższych wskaźników obliczono syntetyczny indeks rozwoju lokalnego (LD). Do obliczenia indeksu wykorzystano sumę normalizowanych wartości wskaźników, z wykorzystaniem odchylenia standardowego i średniej.

W ujęciu przestrzennym wartości wskaźnika rozwoju lokalnego można zauważyć wyraźne zróżnicowanie wschód-zachód i wysokie wartości wokół większych ośrodków miejskich oraz na obszarach górskich - głównie atrakcyjnych turystycznie (rycina 4). Przykładem mogą być turystyczne gminy Cisna i Jaśliska na wschodzie lub miejscowości wokół Zakopanego.

W celu budowy modelu wpływu poziomu rozwoju na zmiany pokrycia terenu w latach 1989-2011 wykorzystano model mieszany (mixed model). W przeprowadzonej analizie zbadano dwa modele. W pierwszym modelu za wartość $y(L D)$ przyjęto obliczony indeks lokalnego rozwoju. W drugim modelu za wartość $y(L C)$ przyjęto zmiany struktury pokrycia terenu. W pierwszym przypadku jako zmienne wykorzystano wskaźniki obrazujące rozwój lokalny w 2011 r. W drugim modelu zmiennymi były wielkości zmiany udziału pokrycia terenu w latach 1990-2012 w poszczególnych klasach (tabela 1).

W pierwszym analizowanym modelu żadna ze zmiennych nie spełniła istotności statystycznej na poziomie 0,05 dla wszystkich badanych miejscowości, dlatego modelowanie przeprowadzono ze względu na regiony fizycznogeograficzne. W przypadku Pogórza 
Rycina 4. Wartości wskaźnika indeksu rozwoju lokalnego (LD) w miejscowościach w polskich Karpatach dla lat 2009-2012

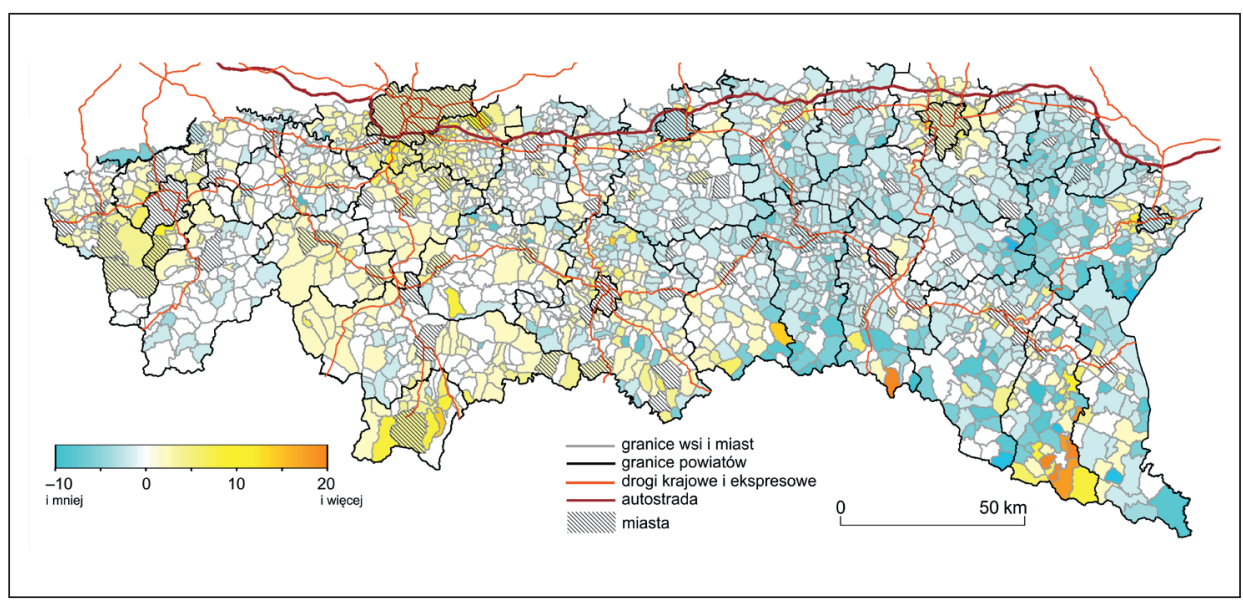

Źródło: opracowanie własne

Środkowobeskidzkiego (rycina 1 - (11)) istotne statystycznie okazały się zmiany terenów zajętych przez budowy, których średnią zmianę oszacowano na 3,1 (p = 0,0001) w stosunku do zmiany o jedną jednostkę zmiany gęstości zaludnienia. Gruntowna analiza wykazała jednak, że przy bardzo małym udziale tej klasy pokrycia terenu (minimalny wyznaczany poligon w CLC to $25 \mathrm{ha}$ ) wpływ na tę sytuację miały pojedyncze poligony związane z dużymi inwestycjami w Rzeszowie i Przemyślu. W przypadku klas pokrycia terenu, które na badanym obszarze mają największe udziały, wyniki analizy uwypukliły głębsze zależności. W przypadku Pogórza Środkowobeskidzkiego, Beskidów Zachodnich oraz Pogórza Zachodniobeskidzkiego (rycina 1 - (11)(7)i(6) zaobserwowano wzrost zabudowy luźnej, a jej szacunek wyniósł 0,1 punktu $(\mathrm{p}=0,0001)$.

W przypadku drugiego modelu zmiana struktury pokrycia terenu powiązana była z liczbą podmiotów gospodarczych na 100 osób $(\mathrm{p}=0,0006)$, choć i w tym przypadku wartość była niewielka i wyniosła 0,1 . W przypadku analizy na poziomie regionów w drugim modelu tylko w Kotlinie Sandomierskiej (rycina 1 - (10)) powiązano zmianę gęstości zaludnienia ze zmianą struktury pokrycia terenu na poziomie 0,2 . W przeprowadzonym modelowaniu także wartość długości geograficznej miejscowości (ustalona na podstawie centroidu) miała bardzo mały, ale istotny statycznie wpływ na zmianę pokrycia terenu, co potwierdza zróżnicowanie społeczno-gospodarcze wschód-zachód badanego terenu.

Region Karpat ze względu na swoje ukształtowanie oraz cenne zasoby przyrodnicze, kulturowe i naturalne stanowi ważny region turystyczny. Jak zauważyła J. Plit (2016), na przełomie wieków (XX/XXI) nastąpiła zmiana wiejskiego krajobrazu - głównie na obszarach atrakcyjnych turystycznie. Potwierdza to przeprowadzona powyżej analiza przemian pokrycia terenu. Dlatego w końcowej analizie podjęto szczegółową analizę obszarów ściśle powiązanych $z$ branżą turystyczną. W analizie wykorzystano jako mierniki atrakcyjności turystycznej miejscowości statystycznych, wielkość bazy noclegowej, opisanej przez wskaźnik Schneidera i Charvata. Wybrano lata 2009-2011 i dla tego to okresu obliczono wartości średnie. Na tej podstawie opracowano wskaźnik syntetyczny atrakcyjności turystycznej (w oparciu o wartości standaryzowane przez wartość średniej arytmetycznej 
Rycina 5. Średnia zamiana pokrycia terenu w miejscowościach Karpat polskich w latach 1990-2012 w podziale dla miejscowości turystycznych i nieturystycznych

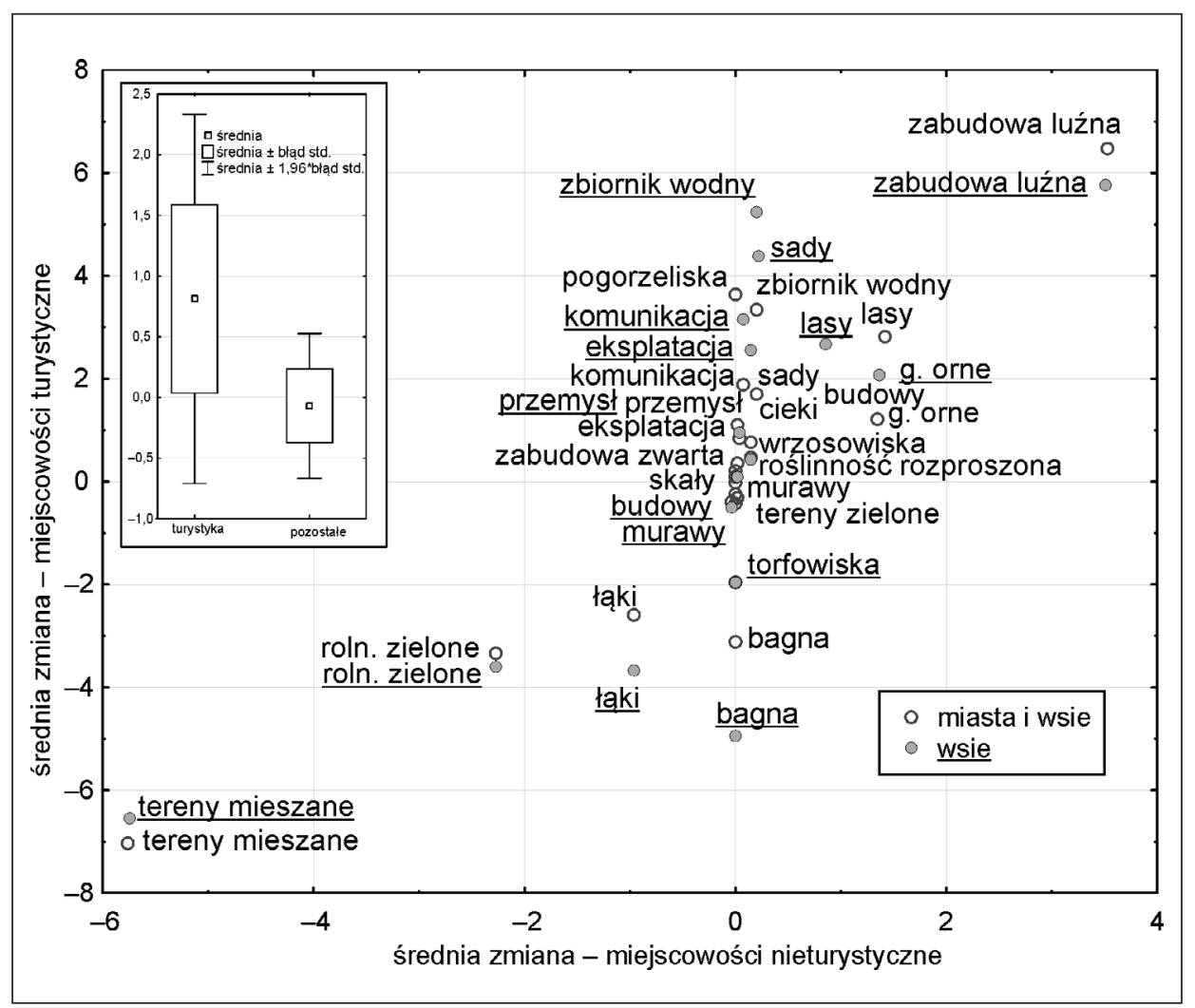

Źródło: opracowanie własne

oraz odchylenia standardowego), tym samym wyróżniając jednostki administracyjne roboczo określane jako „turystyczne” (tam, gdzie występowały funkcje turystyczne) i „nieturystyczne” (tam, gdzie tych funkcji nie było). Ze względu na to, że największe wartości atrakcyjności turystycznej posiadały duże miasta, takie jak np. Kraków, analizę przeprowadzono osobno dla wsi i miast oraz tylko dla wsi. Można przyjąć, iż w świetle tego wskaźnika miejscowości turystyczne mają preferencyjne warunki do zwiększania poziomu rozwoju lokalnego.

W zestawieniu obrazującym wynik dla miejscowości turystycznych i nieturystycznych potwierdziła się hipoteza, że w miejscowościach atrakcyjnych turystycznie nastąpiło większe zróżnicowanie pokrycia terenu (przy większym zróżnicowaniu wyników) (rycina 5). Zarówno w przypadku wszystkich analizowanych miejscowości statystycznych, jak i tylko wsi największy wzrost odnotował udział zabudowy luźnej (w miejscowościach turystycznych o ponad $2 \%$ więcej niż na obszarach nieturystycznych). Największy spadek udziału odnotowały natomiast obszary zaliczane do klas: złożone systemy upraw i działek oraz tereny górskie o dużym udziale rolnictwa. Spadek udziału tych terenów w przypadku miejscowości turystycznych był również większy o ok. 2\% niż przypadku miejscowości nieturystycznych. Nie odnotowano natomiast większej różnicy w zmianach pokrycia terenu 
w przypadku analizy wszystkich miejscowości, jak i samych wsi. Jedynie w przypadku wartości udziału zbiorników wodnych i sadów różnice te były powyżej $2 \%$ dla wsi.

\section{Wnioski}

Dokonując próby odpowiedzi na postawione na początku artykułu pytanie: czy zmiany pokrycia terenu w Karpatach polskich są związane z rozwojem lokalnym, należy odpowiedzieć twierdząco. Jednakże zaznaczyć należy, że zmiany te są bardzo zróżnicowane przestrzennie i zależą od uwarunkowań naturalnych oraz społeczno-ekonomicznych.

Analizując kierunki zmian pokrycia terenu, zaobserwowano wzrost udziału obszarów o luźnej zabudowie, co świadczy o procesach suburbanizacji oraz naporze inwestycyjnym głównie na obszarach podmiejskich i atrakcyjnych turystycznie. Może to świadczyć także o słabości lokalnych władz w aspekcie planowania przestrzennego oraz o wzroście powszechnej w Karpatach zabudowy rozproszonej.

Duże zmiany pokrycia terenu następowały w obszarach turystycznych i były związane $\mathrm{z}$ rozwojem infrastruktury turystycznej oraz zanikiem funkcji rolniczych.

Konkludując, trzeba odnotować, że zachodzi potrzeba dalszych szczegółowych badań zmian pokrycia terenu $\mathrm{w}$ aspekcie rozwoju lokalnego, uwzględniających m.in. lokalne plany zagospodarowania przestrzennego oraz uwarunkowania prawne.

\section{Literatura}

\section{References}

Andrews, D., Sánchez, A.C., Johansson, A. (2011). Housing Markets and Structural Policies in OECD countries. OECD Economics Department Working Papers, 836. doi: 10.1787/5kgk8t2k9vf3-en

Bański, J., (2002). Geografia wsi - nowa dyscyplina badawcza polskiej geografii. Przegląd Geograficzny, 74(3), 367-379.

Bański, J., (2003). Współczesne i przyszłe zmiany w strukturze przestrzennej obszarów wiejskich - wybrane zagadnienia. Studia Obszarów Wiejskich, 4, 11-25.

Bański, J., Stola, W. (2002). Przemiany struktury przestrzennej i funkcjonalnej obszarów wiejskich w Polsce. Studia Obszarów Wiejskich, 3.

Baranowski, M., Ciołkosz, A. (1997). Opracowanie bazy danych „pokrycie terenu Polski”. Prace Instytutu Geodezji i Kartografii, 44(95), 7-25.

Bielecka, E., Ciołkosz, A., (2004). Metodyczne i realizacyjne aspekty aktualizacji bazy Corine Land Cover, Prace Instytutu Geodezji i Kartografii, 50(108), 73-92.

Bossard, M., Feranec, J., Otahel, J. (2000). CORINE land cover technical guide: Addendum 2000. European Environment Agency, 1-105.

Brzosko-Sermak, A., Dorocki, S. (2018). Znaczenie turystyki w rozwoju Krynicy-Zdroju. Przedsiębiorczość - Edukacja, 14, 313-328. DOI: 10.24917/20833296.14.23

Bucała, A. (2014). The impact of human activities on land use and land cover changes and environmental processes in the Gorce Mountains (Western Polish Carpathians) in the past 50 years. Journal of Environmental Management, 138, 4-14. doi:10.1016/j.jenvman.2014.01.036

Bucała, A., Starkel L. (2012). Wpływ gwałtownych i powolnych zmian użytkowania ziemi na przekształcenia środowiska polskich Karpat. Nierówności Społeczne a Wzrost Gospodarczy, 29, 111-117.

CORINE Land Cover. Technical Guide (1994). Brussels: Office for Official Publications of European Commision. 
Čuka, P., Dorocki, S., Rachwał, T., Rettinger, R. (2015). Development of ski infrastructure as a factor of local development vs. environmental sustainability: the case of Krynica-Zdroj (Poland). 15th International Multidisciplinary Scientific GeoConference SGEM 2015, SGEM2015 Conference Proceedings, book 5, vol. 3, 189-196. doi: 10.5593/SGEM2015/B53/S21.024

Czyż, T. (2012). Poziom rozwoju społeczno-gospodarczego Polski w ujęciu subregionalnym. Przegląd Geograficzny, 84(2), 219-236.

Dorocki, S. (2008). Kultura w aspekcie badań geograficznych. W: A. Pankowicz, J. Rokicki, P. Plichta (red.), Tożsamość kulturoznawstwa. Kraków: Wydawnictwo Uniwersytetu Jagiellońskiego, 283-288.

Dorocki, S. (2011). Wpływ kryzysu gospodarczego na przemiany struktur regionalnych Francji. Prace Komisji Geografii Przemystu Polskiego Towarzystwa Geograficznego, 17, 67-86. doi:10.24917/339

Dorocki, S. (2016). Wykorzystanie i stan infrastruktury narciarskiej w gminie Krynica-Zdrój w świetle badań ankietowych. Wyniki badań pilotażowych. Annales Universitatis Paedagogicae Cracoviensis Studia Geographica, 10, 171-187.

Dorocki, S., Brzegowy, P. (2015). Intensyfikacja usług uzdrowiskowych w Polsce po okresie transformacji systemowej. Przedsiębiorczość - Edukacja, 11, 165-176.

Dorocki, S., Brzegowy, P. (2014). Ski and spa tourism as local development strategy - the case of KrynicaZdrój (Poland). Annales Universitatis Paedagogicae Cracoviensis Studia Geographica, 5, 88-116. doi:10.24917/1665

Dorocki, S., Raźniak, P., Obirek, D. (2014). Rozwój infrastruktury narciarskiej w Polsce i na terenie Podhala w świetle badań ankietowych. Prace Komisji Geografii Przemystu Polskiego Towarzystwa Geograficznego, 28, 59-77. doi:10.24917/1833

Dorocki, S., Struś, P. (2017). Przestrzenne zróżnicowanie dynamiki rozwoju lokalnego w Małopolsce na podstawie wybranych cech społeczno-gospodarczych. Prace Komisji Geografii Przemystu Polskiego Towarzystwa Geograficznego, 31(2), 7-25. doi:10.24917/20801653.312.1

Foryś, I. (2011). Społeczno-gospodarcze determinanty rozwoju rynku mieszkaniowego w Polsce: ujęcie ilościowe. Szczecin: Wydawnictwo Naukowe Uniwersytetu Szczecińskiego.

Górz, B., (2003). Społeczeństwo i gospodarka Podhala w okresie transformacji. Kraków: Wydawnictwo Akademii Pedagogicznej.

Grum, B., Temeljotov-Salaj, A. (2010). Pričakovanja potencialnih pridobiteljev stanovanjskih nepremičninskih pravic v republiki sloveniji glede na njihov spol, starost, izobrazbo in zaposlenost. Geodetskivestnik, 54(3), 501-516.

Harańczyk, A. (2015). Przemiany w użytkowaniu gruntów w miastach wojewódzkich w latach 2010 i 2014. Studia Miejskie, 18, 131-146.

Jensen, C. (2018). The employment impact of Poland's special economic zones policy. Regional Studies, 52(7), 877-889.

Kaim, D., (2009). Zmiany pokrycia terenu na pograniczu polsko-słowackim na przykładzie Małych Pienin. Przeglad Geograficzny, 81(1), 93-105.

Kilar, W., Kurek, S., Osuch, W., Świętek, A., Rachwał, T. (2016). Koncepcja oceny i kształtowania postaw przedsiębiorczych na podstawie narzędzi wypracowanych w ramach projektu RLG. Przedsiębiorczość - Edukacja, 12, 426-443. doi:10.24917/3173

Kozak, J., (2005). Zmiany powierzchni lasów w Karpatach polskich na tle innych gór świata. Kraków: Uniwersytet Jagielloński.

Kroczak, R., Fidelus-Orzechowska, J., Bucała-Hrabia, A., Bryndal, T. (2018). Land use and land cover changes in small Carpathian catchments between the mid-19th and early 21st centuries and their record on the land surface. Journal of Mountain Science, 15(12). doi: 10.1007/s11629-018-5095-y

Kukliński, A., (2007). Polska przestrzeń w perspektywie długiego trwania W: P. Jakubowska, A. Kukliński, P.Żuber (red.), Problematyka przyszłości regionów. W poszukiwaniu nowego paradygmatu. Warszawa: Ministerstwo Rozwoju Regionalnego, 236-243.

Mach, Ł., (2012). Determinanty ekonomiczno-gospodarcze oraz ich wpływ na rozwój rynku nieruchomości mieszkaniowych. Ekonometria, 4(38), 106-116. 
Maslow, A.H. (1987). Motivation and Personality, London: Longman.

Matyka, M. (2012). Analiza regionalnego zróżnicowania zmian w użytkowaniu gruntów w Polsce. Polish Journal of Agronomy, 10, 16-20.

Mika, M., (2012). Kierunki i cechy rozwoju drugich domów w polskich Karpatach w świetle stanu badań. Czasopismo Geograficzne, 83(1-2), 63-79.

Mika, M., Faracik, R. (2008). Second homes as a factor of the transformation of rural areas in the Polish Carpathians. Folia Geographica, 12, 245-255.

Plit, J. (2016). Krajobrazy kulturowe Polski i ich przemiany. Prace Geograficzne, 253.

Poławski, Z. F. (2009). Zmiany użytkowania ziemi w Polsce w ostatnich dwóch stuleciach. Teledetekcja Środowiskowa, 42, 69-82.

Ptaszycka-Jackowska, D. (2007). Gospodarowanie przestrzenią turystyczną w polskich Karpatach. Prace Geograficzne, 117, 99-112.

Rachwał, T. (2010). Struktura przestrzenna i działowa przemysłu Polski na tle Unii Europejskiej w dwudziestolecie rozpoczęcia procesów transformacji systemowej. Prace Komisji Geografii Przemystu Polskiego Towarzystwa Geograficznego, 16, 105-124. doi:10.24917/362

Rachwał, T. (2011). Wpływ kryzysu na zmiany produkcji przemysłowej w Polsce. Prace Komisji Geografii Przemysłu Polskiego Towarzystwa Geograficznego, 17, 99-113.

Serafin, P. (2016). Rozlewanie się miast na przykładzie Nowego Sącza w województwie małopolskim. Prace Naukowe Uniwersytetu Ekonomicznego we Wrocławiu, 443, 204-219.

Sikora, J. (2012). Analiza zmian struktury użytkowania gruntów w gminach o charakterze turystycznym województwa małopolskiego. Infrastruktura i Ekologia Terenów Wiejskich, 3(4), 99-108.

Soja, M. (2008). Cykle rozwoju ludności Karpat polskich w XIX i XX wieku. Kraków: Instytut Geografii i Gospodarki Przestrzennej UJ.

Solon, J., Borzyszkowski, J., Bidłasik, M., Richling, A., Badora, K., Balon, J., Jodłowski, M. (2018). Physico-geographical mesoregions of Poland: Verification and adjustment of boundaries on the basis of contemporary spatial data. Geographia Polonica, 91(2), 143-170. doi: 10.7163/GPol.0115

Sołtys, J., Dorocki, S. (2016). Wskaźnik przedsiębiorczości w jednostkach terytorialnych Polski - zróżnicowanie w czasie i przestrzeni. Przedsiębiorczość - Edukacja, 12, 18-35. doi: 10.24917/3134

Sroka, W. (2014). Struktura oraz intensywność użytkowania gruntów rolnych w miastach i na obszarach podmiejskich. Roczniki Naukowe Stowarzyszenia Ekonomistów Rolnictwa i Agrobiznesu, 16(6), 449-455.

Szymańska, D., Grzelak-Kostulska, E., Hołowiecka, B., (2006). Zmiany powierzchni i gęstości zaludnienia miast Polski w latach 1960-2003. W: J. Słodczyk, E. Szafranek (red.), Kierunki przekształceń struktury gospodarczej i społeczno-demograficznej miast. Opole: Wydawnictwo Uniwersytetu Opolskiego, 341-353.

Trzepacz, P. (2011). Kierunki zmian zagospodarowania przestrzeni w Karpatach polskich na przełomie XX i XXI wieku. W: A. Ciołkosz, C. Guzik, M. Luc, P. Trzepacz (red.), Zmiany użtkowania ziemi w Karpatach polskich w okresie 1988-2006. Kraków: Instytut Geografii i Gospodarki Przestrzennej UJ, 113-120.

Warszyńska, J. (red.). (1996). Karpaty polskie, Kraków: Wydawnictwo Uniwersytetu Jagiellońskiego.

Witakowski, P. (red.) (2007). Raport 2006 o naprawie sytuacji mieszkaniowej. Praca zespołowa wykonana $w$ trybie społecznym, Warszawa. Pozyskano z: https://fio.org.pl/images/dodatki/20070516_ mieszk_rap2006.pdf

Wolski, R., Załęczna, M. (2007). Mieszkanie jako alternatywna inwestycja. Studia i Materiały Towarzystwa Naukowego Nieruchomości. Rynek nieruchomości - analizy, modelowanie, inwestowanie, 15(3-4), 105-119.

Zarzycki, J., Korzeniak, J. (2013). Łąki w polskich Karpatach - stan aktualny, zmiany i możliwości ich zachowania. Roczniki Bieszczadzkie, 21, 18-34.

Zegar, J.S. (2012). Rola drobnych gospodarstw rolnych w procesie społecznie zrównoważonego rozwoju obszarów wiejskich. Problemy Drobnych Gospodarstw Rolnych, 1, 129-148. 
Ziemiańczyk, U. (2010). Ocena poziomu rozwoju społeczno-gospodarczego gmin wiejskich w województwie małopolskim. Infrastruktura i Ekologia Terenów Wiejskich, 14, 31-40.

Zioło, Z. (2007). Rola przedsiębiorczości w aktywizacji gospodarczej - zarys modelu. Przedsiębiorczość Edukacja, 3, 10-17. doi:10.24917/604

Sławomir Dorocki, dr, absolwent studiów z zakresu geografii społeczno-ekonomicznej Uniwersytetu Pedagogicznego im. Komisji Edukacji Narodowej w Krakowie, doktor nauk humanistycznych w dyscyplinie historia (Instytut Europeistyki, Uniwersytet Jagielloński). Adiunkt w Instytucie Geografii Uniwersytetu Pedagogicznego w Krakowie. Jego zainteresowania badawcze skupiają się na problematyce regionów i procesów regionalizacji społeczno-gospodarczej, ze szczególnym uwzględnieniem zróżnicowania przestrzeni europejskiej oraz procesów integracji europejskiej i uwarunkowań historycznych oraz zastosowania metod komputerowych i statystycznych w badaniach nad zróżnicowaniem przestrzeni.

Sławomir Dorocki, PhD, Department of Entrepreneurship and Spatial Management, Institute of Geography, Pedagogical University of Cracow. Sławomir Dorocki has graduated from the Pedagogical University of Cracow with an MA degree in Geography. He holds a PhD in History (Institute of European Studies of the Jagiellonian University). He is an associate professor at the Pedagogical University of Cracow, Institute of Geography. His research interests are connected with regional problems and processes of socio-economic regionalisation, with particular emphasis on the diversity of Europe, processes of European integration, historical conditions, and the application of computer and statistical methods in the study of diversity of space.

ORCID: 0000-0001-6083-0346

\section{Adres/Address:}

Uniwersytet Pedagogiczny im. Komisji Edukacji Narodowej w Krakowie

Instytut Geografii

Zakład Przedsiębiorczości i Gospodarki Przestrzennej

ul. Podchorążych 2

30-084 Kraków, Polska

e-mail: sdorocki@up.krakow.pl

Rafał Kroczak, dr, absolwent studiów z zakresu geografii, doktor nauk o Ziemi. Obecnie adiunkt w Instytucie Geografii Uniwersytetu Pedagogicznego im. Komisji Edukacji Narodowej w Krakowie. Jego zainteresowania badawcze skupiają się na zmianach w użytkowaniu i pokryciu terenu w obszarach górskich, wpływach człowieka na obieg energii i materii w środowisku górskim oraz wykosztowaniu GIS i teledetekcji do budowy baz danych.

Rafał Kroczak, $\mathrm{PhD}$, geographer, researcher and academic teacher in the Department of Physical Geography at the Pedagogical University of Cracow. Research interests related to: land use and land cover changes in the mountains, hydrological and geomorphological aspects of human impact on mountains environment, GIS and remote sensing data collection.

ORCID: 0000-0002-6268-7843

\section{Adres/Address:}

Uniwersytet Pedagogiczny im. Komisji Edukacji Narodowej

Instytut Geografii

Zakład Geografii Fizycznej

ul. Podchorążych 2

30-084 Kraków, Polska

e-mail: kroraf@up.krakow.pl 
Tomasz Bryndal, dr hab., geograf, pracownik w Zakładzie Geografii Fizycznej Uniwersytetu Pedagogicznego im. Komisji Edukacji Narodowej w Krakowie. Jego zainteresowania badawcze związane są m.in. $\mathrm{z}$ analizą zmian użytkowania i pokrycia terenu w obszarach górskich i ich wpływem na antropogeniczną składową obiegu wody w małych zlewniach karpackich.

Tomasz Bryndal, geographer, associate professor in the Department of Physical Geography at the Pedagogical University of Cracow. Research interests related to: land use and land cover changes in mountain areas in the context of anthropogenic part of the water circulation in small Carpathians catchments.

ORCID: 0000-0003-4953-2756

\section{Adres/Address:}

Uniwersytet Pedagogiczny im. Komisji Edukacji Narodowej

Instytut Geografii

Zakład Geografii Fizycznej

ul. Podchorążych 2

30-084 Kraków, Polska

e-mail: tbryndal@up.krakow.pl 